\title{
POLYKETONES AND POLYSULFONES FOR CONSERVATION IN THE ETHYLENE POLYMER INDUSTRY
}

PROGRESS REPORT NO. 6 JULY-SEPTEMBER 1979

Meyer Steinberg, Richard Johnson, David Elling, WilLIam Cordes and Donald GOOdMan

January 1980

DEPARTMENT OF ENERGY AND ENVIRONMENT

BROOKHAVEN NATIONAL LABORATORY UPTON, NEW YORK 11973 


\section{DISCLAIMER}

This report was prepared as an account of work sponsored by an agency of the United States Government. Neither the United States Government nor any agency Thereof, nor any of their employees, makes any warranty, express or implied, or assumes any legal liability or responsibility for the accuracy, completeness, or usefulness of any information, apparatus, product, or process disclosed, or represents that its use would not infringe privately owned rights. Reference herein to any specific commercial product, process, or service by trade name, trademark, manufacturer, or otherwise does not necessarily constitute or imply its endorsement, recommendation, or favoring by the United States Government or any agency thereof. The views and opinions of authors expressed herein do not necessarily state or reflect those of the United States Government or any agency thereof. 


\section{DISCLAIMER}

Portions of this document may be illegible in electronic image products. Images are produced from the best available original document. 


\title{
POLYKETONES AND POLYSULFONES FOR CONSERVATION IN THE ETHYLENE POLYMER INDUSTRY
}

\author{
PROGRESS REPORT NO. 6 \\ JULY-SEPTEMBER 1979
}

Contributors:

\author{
Meyer Steinberg William Cordes* \\ Richard Johnson . Donald Goodman* \\ David Elling \\ *Affiliated with Tenneco Chemicals, Inc., Piscataway, New Jersey \\ January 1980 \\ WORK PERFORMED FOR THE \\ DIVISION OF INDUSTRIAL ENERGY CONSERVATION \\ UNITED STATES DEPARTMENT OF ENERGY \\ WASHINGTON, D.C. 20545
}

M. Steinberg, Head

R. Johnson, Project Leader

PROCESS SCIENCES DIVISION

\section{DEPARTMENT OF ENERGY AND ENVIRONMENT BROOKHAVEN NATIONAL LABORATORY ASSOCIATED UNIVERSITIES, INC.}

UNDER CONTRACT NO. DE-AC02-76CH00016 WITH THE

\section{UNITED STATES DEPARTMENT OF ENERGY}




\section{DISCLAIMER}

This book was prepared as an account of work sponsored by an agency of the United States Government. Neither the United States Government nor any agency thereof, nor any of their employees, makes any wairanty, cxpress or implied, or assumes any legal liability or responsibility for the accuracy, completeness, or usefulness of any information, apparatus, product, or process disclosed, or represents that its use would not infringe privately owned rights. Reference herein to any specific commercial product, process, or service by trade name, trademark, manufacturer, or otherwise, does not necessarily constitute or imply its endorsement, recommendation, or favoring by the United States Government or any agency thereof. The views and opinions of authors expressed herein do not necessarily state or reflect those of the United States Government or any agency thereof.

Printed in the United States of America

Available from

National Technical Information Service

U.S. Department of Commerce

5285 Port Royal Road

Springfield, VA 22161

Price: Printed Copy $\$ 4.50$; Microfiche $\$ 3.00$ 


\section{Table of Contents}

Summary ......................... . . . v v

I. Introduction ...................... 1

II. Polyketones - Characterization Studies by TCI . . . . . . 2

A. Polymer Structure .............. 3

B. Thermal Degradation ............. 7

C. Conclusions ................. 10

III. Polysulfones - Reaction Kinetics and Characterization . . . . 11

A. Low-Pressure Gas-Phase Co-60 Gamma Copolymerization of $\mathrm{Et}-\mathrm{SO}_{2}$ in Recharged Systems ......... 11

B. Low-Pressure Gas-Phase Co-60 Gamma Copolymerization of Et-SO 2 Mixtures Containing Hydrogen... . . . .

C. Low-Pressure Gas-Phase Co-60 Gamma Copolymerization of Et-SO ${ }_{2}$ Mixture Containing Oxygen . . . . . .

D. Low-Pressure Gas-Phase Co-60 Gamma Copolymerization of 1-Butene- $\mathrm{SO}_{2}$. . . . . . . . . . . . . . . .

E. Thermal Property and Infrared Measurements of Propylene-SO ${ }_{2}$ and 1-Butene-SO ${ }_{2}$ Copolymers . . . .

F. Conclusions . . . . . . . . . . . . . 16

IV. Relocation of the Copolymer Studies Experimental Facility . . 17 References ..................... 
THIS PAGE

\section{WAS INTENTIONALLY LEFT BLANK}




\section{POLYKETONES AND POLYSUTONES FOR CONSERVATION}

IN THE ETHYLENE POLYMER INDUSTRY

Progress Report No. 6

July-September 1979

\section{Summary}

The characterization study by Tenneco Chemicals Incorporated (TCI) on ethylene-CO (Et-CO) copolymers was concluded. The copolymers were prepared at various levels of co composition, and with several methods of catalysis, including free-radical, metallic, and co-60 irradiation. Et-CO copolymers exhibit crystallinity related to the alternating polyketone structure which increases logarithmically with Co content over the range $28 \%$ to $49 \% \mathrm{CO}$. The melting point increases in essentially the same manner as crystallinity. The structure of the copolymers is" independent of the type of catalysis used. Highly crystalline copolymers showed discoloration and loss of crystallinity at $140^{\circ} \mathrm{C}$; whether in air or $\mathrm{N}_{2} \cdot$ Discoloration is severe at $210^{\circ} \mathrm{C}$, and after heating at $280^{\circ} \mathrm{C}$ for $1 \mathrm{hr}$, essentially all crystallinity was lost. Thermal degradation, as characterized by loss of crystallinity, evolution of water, and formation of olefinic unsaturation, has been described in the literature as crotonic self-condensation. Press molding of highly crystalline copolymer at $260^{\circ} \mathrm{C}$ for 5 minutes showed $38.8 \%$ loss of crystallinity and appearance of $\mathrm{H}_{2} \mathrm{O}$ and olefinic unsaturation.

Reaction kinetic studies on the low-pressure ( $<5$ atm) gas-phase copolymerization of ethylene $-\mathrm{SO}_{2}\left(\mathrm{Et}-\mathrm{SO}_{2}\right)$ mixtures at a dose rate of $0.54 \mathrm{Mrad} / \mathrm{hr}$ and at $10-13^{\circ} \mathrm{C}$ were continued. Recharging a reaction system repeatedly with 
a mixture containing 19.2 mole $\% \mathrm{SO}_{2}$ initially resulted in a general increase in G-value from $4.60 \times 10^{4}$ to $7.10 \times 10^{4}$ molecules $/ 100 \mathrm{eV}$ and a factor of 4.6 decrease in reaction time for the attainment of peak rate and G-value. A 19.2 mole $\% \mathrm{SO}_{2}$ mixture with 5 mole \% $\mathrm{H}_{2}$ showed a slight decrease in reactivity, whereas a 10 mole $\% \mathrm{H}_{2}$ mixture showed a slight increase in reactivity when compared with previous data for mixtures containing helium or nitrogen. A 19.2 mole \% $\mathrm{SO}_{2}$ mixture containing $1 \%$ oxygen initially showed a factor of 6.7 increase in reaction time for the attainment of peak rate and G-value when compared with a mixture containing no oxygen. Lowpressure (< 5 atm) gas-phase Co-60 gamma copolymerization at a dose rate of $0.56 \mathrm{Mrad} / \mathrm{hr}$ and at $10-13^{\circ} \mathrm{C}$ of a 1 -butene- $\mathrm{SO}_{2}$ mixture of approximately equimolar composition resulted in peak and overall G-values of 340 and 156 , respectively, and product of nearly equimolar composition. Differential scanning caloptmetry, thermogravimetric analysis and infrared spectroscopy were use to characterize propylene- $\mathrm{SO}_{2}$ and 1-butene- $\mathrm{SO}_{2}$ copolymers.

For safety reasons the experimental radiation facility for conducting the copolymer studies was relocated to another building and a $5300 \mathrm{Ci}$ Co-60 gamma radiation source was transferred to the new facility.

A subcontract task was written for engaging the International. Nickel Co. (INCO) to evaluate the $\mathrm{Et}^{-\mathrm{SO}_{2}}$ copolymers produced for assessing eventual market applications. 
POLYKETONES AND POLYSUFONES FOR CONSERVATION

IN THE ETHYLENE POLYMER INDUSTRY

Progress Report No: 6

July-September 1979

\section{Introduction}

The objectives of this program are: (1) prepare polyketones and polysulfones copolymers by the partial substitution of $\mathrm{CO}$ and $\mathrm{SO}_{2}$ for ethylene; and (2) determine their usefulness in industry as a means of substituting low-cost energy-conserving materials in the ethylene polymer and copolymer market. ${ }^{1-6}$

In the case of the polyketones, a joint program was estabished between Brookhaven National Laboratory (BNL) and Tenneco Chemicals, Inc. (TCI) to prepare and evaluate ethylene-CO (Et-CO) copolymers. These copolymers were prepared by Co-60 radiation-induced means at BNL and also by free-radical and metallic catalysts at Battelle Columbus Laboratories and Pressure Chemicals Inc. for analysis and characterization by Tenneco Chemicals Inc. (TCI). The results of TCI's structural and thermal degradation study is included in this report. Because of the crossilinking on thermoset effect of the copolymers at elevated temperature, processing difficulty would preclude their use as thermoplastics in commercial applications unless suitably modified or stabilized. The $R \& D$ effort required to overcome this problem is greater than TCI's present commitment would allow; therefore, TCI is disengaging from the program at this time. The results of the TCI studies are reported therein.

In the case of polysulfones, a similar program with the International N1ckel Company, Inc. (INCO) has been initiated. Ethylene-SO $2\left(\mathrm{Et}-\mathrm{SO}_{2}\right)$. copolymers have been prepared by BNL in both 1iquid and gas phase over a 
wide range of pressure to study the reaction kinetics and INCO has begun to characterize and evaluate the product.

In the present period, reaction kinetic studies were continued on the Et- $-\mathrm{SO}_{2}$ system. In addition the propylene- $\mathrm{SO}_{2}$ and the 1-butene- $\mathrm{SO}_{2}$ system were briefly investigated. Propylene- $\mathrm{SO}_{2}$ and 1-butene- $\mathrm{SO}_{2}$ copolymers were characterized by thermal analysis and infrared spectroscopy. For the copolymer studies the Co-60 gamma radiation experimental facility was relocated to a separate building for reasons of safety. Future work will include studies on Co-60 gamma radiation copolymerization of $\mathrm{Et}^{-\mathrm{SO}_{2}}$ mixtures with various additive monomers.

II. Polyketones - Characterization Studies by TCI

This section covers polymer characterization and analysis work by TCI on Et-CO copolymers prepared by BNL, Battelle Columbus Laboratories, and Pressure Chemicals Inc. The polymers were prepared at various levels of CO incorporation, and with several methods of catalysis, including freeradical, metallic, and $\mathrm{Co}^{60}$ irradiation. This investigation was performed to determine the following:

(1) The structure of the copolymers, as influenced by composition and method of preparation;

(2) The nature and rate of thermal degradation of the copolymers.

The study of polymer structure as a function of composition and method of preparation was instituted to determine whether polymers prepared by co-60 irradiation are suitable as models for the study of physical and mechanical properties of catalyst-free metal-catalyzed polymers. The investigation of thermal degradation was performed to characterize those changes with melting which have previously been described as crosslinking or thermoset character. Of particular interest is the determination of whether press 
molding of the polymer to prepare specimens for testing causes significant changes in polymer structure. This would indicate the type of stabilization required and provide information on the processability of the polymers.

\section{A. Polymer Structure}

Et-CO polymers produced at Battelle Columbus Laboratories during the early stages of this program were analyzed by various techniques to determine the nature of these polymers. They were low melting, waxy materials which were partially or totally soluble in $\mathrm{CHCl}_{3}$. All were well below 50\% Co, and none showed useful mechanical properties. At this time, polymer characterization work on incoming samples was reduced to include only thermal analysis, tensile testing of press molded specimens, and elemental analysis (\% $, \mathrm{H}, 0$ performed by an outside laboratory). No further study of polymer structure was made until the present investigation was initiated.

Samples prepared by metal catalysis at high levels of co were found to have tensile properties which indicated the polymers might have commercial utility. One major disadvantage of these polymers, however, is the difficulty in removing the relatively large amounts of metal catalysts from the polymer. Since samples produced by Co-60 irradiation approached the metal material in tensile properties without the problem of catalyst removal, it was proposed that these polymers be studied as models for catalyst-free metal materials in processing, stabilization, and compounding studies. To test the validity of this proposai, comparisons of the structure of metal and Co-60 prepared polymers were begun. Included in the study were several samples of polymers which had previously been evaluated by tensile testing, and 25 freshly prepared samples produced at BNL by Co-60 irradiation. 
In order to insure that-all structural information obtained would relate to the polymers as prepared, only the powders as received were included in this study. Pressed plaques of previously tested samples were purposely avoided because of the possibility of thermal degradation. Infrared spectra were obtained by grinding $1.5 \mathrm{mg}$ samples with $125 \mathrm{mg} \mathrm{KBr}$ in the presence of hexafluoroisopropanol to aid in dispersion. Solvent was removed by heating in a vacuum oven at $70^{\circ} \mathrm{C}$ for 20 minutes and the polymer $-\mathrm{KBr}$ mixture was pressed into a pellet at room temperature. Spectra were scanned from 4000 to $250 \mathrm{~cm}^{-1}$ in 15 minutes using a Perkin Elmer model 521 grating spectrophotometer.

The IR spectra obtained in this way show the copolymers to be polyketones of apparently alternating Et-CO comonomer sequence. All samples show the ketone carbonyl near $1700 \mathrm{~cm}^{-1}$ as the strongest band with strong absorption at $1400 \mathrm{~cm}^{-1}$ due to $\mathrm{C}-\mathrm{H}$ deformation of methylene groups adjacent to carbonyl. C-H stretching absorption near $2920 \mathrm{~cm}^{-1}$ decreases with increasing CO content, and absorption at $720 \mathrm{~cm}^{-1}$ due to $\mathrm{C}-\mathrm{H}$ wag for four or more adjacent methylene groups is detectable only in the lowest co content sample examined $(28.7 \%$ Co $)$. Little, if any, unsaturation or hydroxyl absorption is present, although. all samples show a fairly strong carbonyl overtone near $3400 \mathrm{~cm}^{-1}$. Significant differences were observed between samples having different levels of $\mathrm{CO}$. These are described as follows:

(1) Absorption near $1450 \mathrm{~cm}^{-1}$, due to $\mathrm{C}-\mathrm{H}$ deformation of $\mathrm{CH}_{2}$ not adjacent to $\mathrm{C}=0$. This band decreases as \% $\mathrm{CO}$ increases, and becomes nondetectable at approximately $49 \% \mathrm{CO}$.

(2) Absorption near $1360 \mathrm{~cm}^{-1}$, probably due to a $\mathrm{C}-\mathrm{H}$ deformation of methylene groups shifted to lower frequency by localized ordering. 
(Although this band is in the region normaliy assigned to $\mathrm{C}-\mathrm{H}$ deformation of terminal methyl groups, it is certainly not methyl absorption in these samples because of the very weak $\mathrm{CH}_{3}$ stretching absorption in all samples examined.) This band decreases sharply in intensity above $42 \% \mathrm{CO}$ and is replaced by the band at $1325 \mathrm{~cm}^{-1}$ described below.

(3) Absorption near $1325 \mathrm{~cm}^{-1}$, probably due to a $\mathrm{C}-\mathrm{H}$ deformation of methylene groups strongly shifted to lower frequency by a high degree of ordering. This band was observed at $1338 \mathrm{~cm}^{-1}$ by Braudo et al. ${ }^{7}$ (all bands in their spectra were shifted about $15 \mathrm{~cm}^{-1}$ to higher frequencies) and assigned to the crystalline structure of the polyketone based on its disappearance in $\mathrm{CHCl}_{3}$ solution. This band increases sharply in intensity above $42 \%$ CO as the band at $.1360 \mathrm{~cm}^{-1}$ decreases.

(4) Absorption near 800 and $585 \mathrm{~cm}^{-1}$, of unknown origin, possibly skeletal vibrations. These bands increase sharply at high co levels, similar to the increase in absorption at $1325 \mathrm{~cm}^{-1}$, and are believed also to be due to the crystalline structure of the polyketone.

In addition to the specific bands listed above, increase in $C 0$ content towards the perfectly alternating linear 50\% copolymer shows a marked sharpening of bands at $2920,1400,1325,1050,800$, and $585 \mathrm{~cm}^{-1}$. This is commonly observed with crystalline materials. The IR spectra, Figs. 1-3, illustrate these changes with increasing co content for polymers prepared with different methods of catalysis. Figures 2 and 3 illustrate the similarity of polymers of similar composition prepared by Co-60 irradiation 
and metal catalyst. At both high and intermediate levels of co content, polymer structure was found to be independent of the method of preparation.

In order to quantify the spectral changes observed with composition, the absorption of bands at $1450,1400,1325$, and $800 \mathrm{~cm}^{-1}$ was measured for all polymers analyzed. Since it was not possible to obtain the same degree of dispersion of the polymers in $\mathrm{KBr}$ pellet preparation, some of the spectra have stronger absorption throughout the entire spectral range than others. To compensate for this, absorbances of bands at 1450, 1325, and $800 \mathrm{~cm}^{-1}$ were normalized to the absorbance at $1400 \mathrm{~cm}^{-1}, \mathrm{CH}_{2}$ adjacent to $\mathrm{C}=0$. This technique is really valid only for samples of similar composition, but cause only minor error when all samples differ only slightly in composition. The error introduced, even when it becomes significant (as in the $28.7 \%$ Co sample), will tend to minimize rather than maximize the differences which exist between samples of greatly differing composition, thus making this normalization technique a conservative method for comparison of spectral data. The raw and normalized absorbances of all samples analyzed is listed in the attached Table 1 , along with co content, melting point, and type of catalysis. The melting points are peak melting points obtained from differential scanning calorimetry (DSC) analysis.

Figure 4 is a plot of the normalized absorbance at $1450 \mathrm{~cm}^{-1}\left(\mathrm{CH}_{2}\right.$ not adjacent to $\mathrm{C}=0$ vs $\% \mathrm{CO}$. As expected, this gives a straight line plot which approaches 0 near $50 \% \mathrm{CO}$, since the absorbance at 1450 is related directly to composition and is not significantly affected by crystallinity. In contrast, eigure 5 shows the nearly logarithmic increase in absorbance at 1325 and $800 \mathrm{~cm}^{-1}$ with increasing co content. Both of these bands are related to polymer crystallinity, and as expected, increase greatly in intensity as the perfectly alternating 50/50 copolymer structure is approached. 
In order to determine the relationship between composition, crysta1linity, and peak melting point determined by DSC, both melting point and normalized absorbance at $1325 \mathrm{~cm}^{-1}$ were plotted against \%co on the same linear graph. The resulting plot, Figure 6 , shows the direct parallel between melting point and crystallinity of these polymers, and indicates the validity of the use of the normalized absorbance at $1325 \mathrm{~cm}^{-1}$ as a quantitative measure of this crystallinity.

In all of the relationships plotted in Figures $4-6$, polymers prepared by free-radical, metal, and Co-60 polymerization techniques were included. No deviations were observed in any of the plots which indicate differences in polymer structure as a result of method of preparation. IR spectra of polymers of similar composition were found to be qualitatively and quantitatively identical regardless of the method of preparation.

\section{B. Therma1 Degradation}

Early attempts to study the melt rheology, thermal stability under mechanical shear, and press molding of Et-CO copolymers showed strong evidence of thermal instability. This was characterized as crosslinking or thermoset character based on the observed physical changes in samples when heated to the melt. This thermal instability is well documented in the literature on these polymers, and was described by Braudo et al. ${ }^{7}$ as the result of crotonic self-condensation of the copolymer. This condensation was characterized by evolution of water, darkening of color due to the formation of unsaturated structures, and a decrease in solubility accompanying the formation of crosslinked rubbery, and finally hard and brittle material with very high melting point. The condensation was found to become very rapid as the polymer was melted, and then to slow down considerably when held at the melt for longer than $1 \mathrm{hr}$. This was believed due to the requirement for high chain mobility 
for the condensation to occur. As the polymer degrades, mobility is reduced by the formation of crosslinked polymer, thus inhibiting further condensation.

In order to study the thermal degradation of high $\mathrm{CO}$ content polymers prepared by Co-60 irradiation and metal catalysis, samples of the polymers as received were heated both in air and in $N_{2}$ for $I$ hr at 70, 140, 210, and $280^{\circ} \mathrm{C}$, and then analyzed by IR in the manner described previously. In addition, one sample of h1ghly crystalline metal catalyzed polymer was analyzed as received, and after press molding at $260^{\circ} \mathrm{C}\left(400^{\circ} \mathrm{F}\right)$ for 5 minutes to prepare specimens for tensile testing. IR data of starting and heated samples is listed in Table 2.

Examination of the heated samples of the white Co-60 irradiated copolymer shows slight discoloration of samples heated at $140^{\circ} \mathrm{C}$ in both air and $\mathrm{N}_{2}$, and severe discoloration after heating at $210^{\circ} \mathrm{C}$, with the sample heated in air turning black while the $\mathrm{N}_{2}$ heated sample was brown. IR spectra of degraded samples show distinct changes from the starting materials as follows:

(1) Loss of crystallinity as measured at $1325 \mathrm{~cm}^{-1}$ upon heating.

(2) Appearance of olefinic unsaturation near 1620 and $1600 \mathrm{~cm}^{-1}$.

(3) Appearance of broad, hydrogen-bonded $\mathrm{OH}$ and broadening of the carbony1 band. These changes may be due to the presence of carboxylic acid and/or entrapped water.

The most striking and readily quantified spectral change with thermal degradation is the loss of crystallinity as determined by absorbance at $1325 \mathrm{~cm}^{-1}$. In Figure 7 this is plotted against temperature for samples of Co-60 and metal-catalyzed polymers heated in air and in $\mathrm{N}_{2}$. Both samples show rapid loss of crystallinity at temperatures above $140^{\circ} \mathrm{C}$, and in both cases decrease in crystallinity was more rapid in air than in $\mathrm{N}_{2}$. The loss 
in crystallinity caused by press molding sample E131-32 (meta1 catalyzed) is approximately equivalent to that expected for heating for $1 \mathrm{hr}$ at $225^{\circ} \mathrm{C}$ in air, as determined from the plot for E-99-143 in Figure 7.

Braudo et al. reported the evolution of $3.4 \%$ water when a Co-60 irradiated copolymer containing $42.4 \% \mathrm{CO}$ (melting point $=150^{\circ} \mathrm{C}$ ) was heated for $1 \mathrm{hr}$ at $200^{\circ} \mathrm{C}$ under vacuum. To confirm the evolution of water and determine the amount generated when high melting, crystalline polymers are heated above their melt, the following two experiments were performed:

(1) Sample E099-70BR was placed in a gas-tight DSC sample pan, heated to $280^{\circ} \mathrm{C}$, and held for $1 \mathrm{hr}$ at this temperature: The pan was then cooled to $0^{\circ} \mathrm{C}$, the cover pierced, and a DSC scan made between -20 and $120^{\circ} \mathrm{C}$. Sharp endotherms were seen near 8.5 and $88^{\circ} \mathrm{C}$ which were not present in the initial DSC scan of the unheated sample. After holding at $120^{\circ} \mathrm{C}$ for 5 minutes to allow volatiles to escape, the pan was cooled and another DSC scan made over the same temperature range. Neither endotherm was present in this run. The pan was then cooled again and $0.4 \mu \mathrm{l}$ distilled water was added to the sample through the perforation in the lid. When the DSC scan was repeated, strong sharp endotherms appeared near 7 and $93^{\circ} \mathrm{C}$. This experiment confirms the evolution of water from a highly crystalline copolymer; indicating the evolution of water to be due to degradation of the alternating polyketone structure itself, rather than to reaction at chain irregularities which would be present in the $42.4 \% \mathrm{CO}$ polymer studied by Braudo et a1. The shifting of the melt and boiling endotherms of evolved water and added water is probably related to the presence of water soluble 
impurities in the heated sample, and to the differing degree of contact between water, polymer, and other impurities between evolved water and added water.

(2) Another sample of this same polymer was placed in a clean, dry Parr Bomb, tightly sealed, and heated in an oven at $280^{\circ} \mathrm{C}$ for $1 \mathrm{hr}$. After cooling, the bomb was opened, rinsed with dry methanol, and the moisture content of the methanol rinse was determined by Karl Fisher titration. 'l'he amount of water found was $6.34 \%$ of the weight of the starting polymer. Based on the composition of this sample as $49.1 \%$ co determined by elemental analysis, this represents one molecule of water produced for each 4.98 co units in the polymer. The amount of water collected by Braudo et al. from a $42.4 \% \mathrm{CO}$ polymer in $1 \mathrm{hr}$ at $200^{\circ} \mathrm{C}$ corresponds to 1 molecule of water for each 8.01 co units. This indicates the severity of crosslinking which may be encountered at the high temperatures required for melt processing of the high melting, highly crystalline 1:1 Et-CO copolymers prepared by co-60 irradiation and metal catalysts.

\section{Conclusions}

(1) Et-CO copolymers exhibit crystallinity related to the alternating polyketone structure which increases logarithmically with co content over the range $28-49 \% \mathrm{Co}$.

(2) The melting point of the copolymers increases with co content in essentially the same manner as the crystallinity.

(3) The structure of the copolymers is independent of the type of catalysis used, with melting points and crystallinity of all polymers following the same relationship to composition. 
(4) Et-CO copolymer of high crystallinity prepared by both Co-60 irradiation and metal catalysis show discoloration and loss of crystallinity when heated at $140^{\circ} \mathrm{C}$, whether in air or $\mathrm{N}_{2}$. Discoloration is severe at $210^{\circ} \mathrm{C}$, and after heating at $280^{\circ} \mathrm{C}$ for $1 \mathrm{hr}$, the polymer lost essentially all of its crystallinity.

(5) Thermal degradation is characterized by loss of crystallinity, evolution of water, and formation of olefinic unsaturation. This decomposition has been described in the literature as a crotonic self-condensation.

(6) Press molding of Et-CO, to prepare placques for testing, causes degradation of the polymer. A highly crystalline, metal-catalyzed polymer pressed for 5 minutes at $250^{\circ} \mathrm{C}$. showed $38.8 \%$ loss of crystallinity and appearance of $\mathrm{H}_{2} \mathrm{O}$ and olefinic unsaturation.

III. Polysulfones-Reaction Kinetics and Characterization

A. Low-Pressure Gas-Phase Co-60 Gamma Copolymerization of Et-SO 2 in Recharged Syștems

Experimental work on Co-60 gamma-induced copolymerization of Et- $\mathrm{SO}_{2}$ mixtures in the gas phase at low pressure ( $<$ atm) was continued. 6 The gas mixtures were irradiated at $0.54 \mathrm{Mrad} / \mathrm{hr}$ in a $2-$ in. $0 . \mathrm{D}$. $x$ 1-in. I.D. vesse $1110 \mathrm{~cm}^{3}$ in volume. As in the previous runs, the vessel was in $\therefore$ in direct contact with the water in the gamma pool maintained at $10-13^{\circ} \mathrm{C}$. The $\ldots$ gas mixtures were prepared from C. P. grade ethylene and anhydrous $\mathrm{SO}_{2}$ supplied by Matheson Gas Products. Pressure measurements were taken by means of a transducer, and from the plot of pressure vs time for each 'run; slope measurements were used to determine polymerization rates and G-values. Runs 339-344 were each made with an $\mathrm{Et}^{-\mathrm{SO}_{2}}$ mixture containing $19.2 \mathrm{~mole}^{2} \mathrm{SO}_{2}$ initially. The reaction system was charged in run 339 and 
recharged in each subsequent run to an initial pressure of 65.2 to 69.4 psia. The vessel was vented and reevacuated, but not disassembled, between runs, and contained a total accumulation of $4.35 \mathrm{~g}$ of product at the end of the six runs.

The results (see Table 3 and Fig. 8) indicate a slight increase in polymerization rate as the sequence of runs progressed. The lowest rate of 1.74 mmoles $/ 1-$ min $(4.80 \mathrm{~g} / 1-\mathrm{hr})$ occurred in run 341 , and the highest rate of 2.82 mmoles/1-min. $(7.78 \mathrm{~g} / 1-\mathrm{hr})$ occurred in the final run 344 . These values correspond to G-values of $4.60 \times 10^{4}$ and $7.10 \times 10^{4}$ molecules $/ 100 \mathrm{eV}$, respectively, and are in general aggreement with values from previous runs 5 made in recharged systems with Et- $\mathrm{SO}_{2}$ mixtures of approximately 1:1 molar ratio. The increase in rate and $G$-value is believed to be due to reduction of the vessel wall inhibition effect as product was built up in each run.

The effect. on the reaction time for attainment of peak rate is more pronounced, however, with the time decreasing by a factor of 4.6 from 236 min for the initial run to 51 min for run 343 . The $\mathrm{SO}_{2}$ concentration at the peak rate is a calculated average value and shows a general increase from $1.6 \mathrm{~mole} \%$ in run 340 to $7.55 \mathrm{~mole} \%$ in run 343 . This increase is possibly due to an increased diffusion effect resulting from build up of product. The product analyses indicated a $1: 1$ molar ratio of $\mathrm{Et}-\mathrm{SO}_{2}$.

\section{B. Low-Pressure Gas-Phase Co-60 Gamma Copolymerization of Et- $\mathrm{SO}_{2}$ Mixtures Containing Hydrogen}

The effect of hydrogen on low-pressure ( $<5 \mathrm{~atm}$ ) gas-phase Co-60 gamma copolymerization of $\mathrm{Et}^{-\mathrm{SO}_{2}}$ mixtures was investigated. The equipment and procedure were described in the previous section. Gas mixtures were prepared from C.P. grade ethylene and anhydrous $\mathrm{SO}_{2}$ and ultra-high purity 
hydrogen (99.999\% minimum) supplied by Matheson Gas Products, and were irradiated at a dose rate of $0.54 \mathrm{Mrad} / \mathrm{hr}$. The mixtures were at 64.7 to 67.3 psia initially and contained 19.2 mole $\% \mathrm{SO}_{2}$ with varying amounts of hydrogen and the balance ethylene.

For comparison, the results (see Table 4) and Fig. 9 include run 339 made under almost identical conditions but without hydrogen and was described in the previous section. The peak rate dropped from 1.84 mmoles/1-min $(5.08 \mathrm{~g} / 1-\mathrm{hr})$ in run 339 made with $0 \% \mathrm{H}_{2}$ to 1.43 and 1.49 mmoles/1-min (3.95 and $4.11 \mathrm{~g} / 1-\mathrm{hr}$ ) in runs 346 and 347 , respectively, made with $5 \% \mathrm{H}_{2}$. The higher $\mathrm{H}_{2}$ concentration of $10 \%$ used in run 345 resulted in only a slightly lower rate of $1.38 \mathrm{mmoles} / 1-\mathrm{min}(3.81 \mathrm{~g} / 1-\mathrm{hr})$. In run 350 , which contained $15 \% \mathrm{H}_{2}$, the rate dropped more significantly to 0.84 moles $/ 1-\mathrm{hr}$ $(2.32 \mathrm{~g} / 1-\mathrm{hr})$. The G-values show corresponding changes and range from $3.54 \times 10^{4}$ to $5.35 \times 10^{4}$ molecules $/ 100 \mathrm{eV}$.

Comparison of these values with comparable data for runs made with helium or nitrogen diluents ${ }^{6}$ show that the rates are lower for mixtures containing 5 mole\%... $\mathrm{H}_{2}$ but higher for mixtures containing 10 mole $\% \mathrm{H}_{2}$. These results thus indicate a possible slight reduction in reactivity for $\mathrm{Et}_{-} \mathrm{SO}_{2}$ mixtures containing 5 mole $\% \mathrm{H}_{2}$ but a slight enhancement at 10 mole $\% \mathrm{H}_{2}$ for the conditions investigated. The reaction time to peak rate, which shows an inverse proportionality, to the reaction rate and G-values, ranged from 236 min for run 339. $\left(0 \% \mathrm{H}_{2}\right)$ to $580 \cdot \mathrm{min}$ for run $350\left(15 \% \mathrm{H}_{2}\right)$.

\section{Low-Pressure Gas-Phase Co-60 Gamma Copolymerization of Et-SO 2 Mixture Containing Oxygen}

The effect of oxygen on low-pressure ( $<5 \mathrm{~atm}$ ) gas-phase co-60 gamma copolymerization of $E t-6 \mathrm{O}_{2}$ was investigated. The equipment and procedure were described in Section II. $\Lambda$ gas mixture containing $19.2 \mathrm{~mole}_{\%} \mathrm{SO}_{2}$ 
and 1.0 mole $\% 0_{2}$ (C.P. grade supplied by Matheson Gas Products) with the balance ethylene was irradiated at a dose rate of $0.54 \mathrm{mrad} / \mathrm{hr}$ at an initial pressure of $65.8 \cdot$ psia.

The rate remained constant at 0.023 moles $/ 1-$ min $(0.0635 \mathrm{~g} / 1-\mathrm{hr})$ for the first 900 min and then increased to a peak of 0.94 moles/1-min) $(2.59 \mathrm{~g} / 1-\mathrm{hr}$ ) after a total of $1345 \mathrm{~min}$ (see Fig. 10, run 351). This peak rate corresponds to a G-value of $2.87 \times 10^{4}$ molecules/100 eV at the peak pressure of 41.5 psia with the $\mathrm{SO}_{2}$ concentration estimated to be $2.84 \mathrm{~mole} \%$. The reaction time for the attainment of peak rate (and G-value) in comparison with run 339 made under almost identical. conditions but with no oxygen (see Section II) shows a 6.7 factor increase in time due to the inhibiting effect of oxygen on free-radical reactions. Subsequent to the initial induction period, the rate shows a more typical increase with time as the inhibiting effect of the oxygen is overcome due to possible formation of peroxide compounds which are known to act as catalytic polymerization initiators.

D. Low-Pressure Gas-Phase Co-60 Gamma Copolymerization of 1-Butene-SO 2

The gas-phase Co-60 gamma-induced copolymerization of 1-butene and $\mathrm{SO}_{2}$ was briefly investigated. In run 319,' a mixture containing $47.9 \mathrm{~mole} \%$ 1-butene (C. P. grade supplied by Matheson Gas Products) and the balance ethylene was irradiated at $0.56 \mathrm{Mrad} / \mathrm{hr}$ and $10-13^{\circ} \mathrm{C}$ in the BNL gamma facility in Bldg. 830. The equipment and procedure were described in Section II.

A peak rate of 0.0228 mmoles $/ 1-$ min $(0.0819 \mathrm{~g} / 1-\mathrm{hr})$ and G-values of 340 molecules $/ 100 \mathrm{eV}$ were attained after $19.2 \mathrm{hr}$. The overall rate was 0.0150 mmoles $/ 1-$ min $(0.377 \mathrm{~g} / 1-\mathrm{hr})$ and overall $\mathrm{G}$-value was 156 . The product was a white powder and weighed $0.377 \mathrm{~g}$. Chemical analysis indicated it to be approximately equimolar in composition. 


\section{E. Thermal Property and Infrared Measurements}

Differential scanning calorimetry (DCS) and thermogravimetric (TGA) and differential thermogravimetric (DTGA) analyses were made on propylene$\mathrm{SO}_{2}$ copolymer from runs 316 and 322 prepared previous $1 \mathrm{y}^{6}$ and on 1 -butene$\mathrm{SO}_{2}$ copolymer from run 319 described in the previous section. The measurements are shown in Figs 11 to 16 and the data from these measurements are summarized in Table 5.

The DSC analyses of the propylene- $\mathrm{SO}_{2}$ copolymers show only a slight indication of a melting or phase transition at 215 and $155^{\circ} \mathrm{C}$ for runs 316 and 322 , respectively. Onset of decomposition was observed at 175 and $200^{\circ} \mathrm{C}$ for the two respective runs compared with $300^{\circ} \mathrm{C}$ for $\mathrm{Et}-\mathrm{SO}_{2}$ copolymer ${ }^{3}$ with DTGA peaks at $325^{\circ} \mathrm{C}$ for both runs. A secondary DTGA peak at $305^{\circ} \mathrm{C}$ was observed in both runs, which was more pronounced in run 322 , indicating the existence of a different polymer material either in composition or structure. Differences in the properties of the two materials are possibly due to: the formation of copolymer under different conditions. In run 316 the reaction was in the gas phase, whereas in run 322 it was in both the gas and 1iquid phase.

The DSC analysis of the 1-butene- $\mathrm{SO}_{2}$ copolymer also shows a weak melting or phase transition peak at $180^{\circ} \mathrm{C}$ but in addition shows a small, distinct peak at $75^{\circ} \mathrm{C}$, possibly due to some butene homopolymer. Onset of decomposition was observed at $150^{\circ} \mathrm{C}$. The peak DTGA occurred at $325^{\circ} \mathrm{C}$ with an indication of a secondary peak at $220^{\circ} \mathrm{C}$.

Infrared spectra of propylene- $\mathrm{SO}_{2}$ product from run 316 and 1-butene- $\mathrm{SO}_{2}$ product from run 319 are shown in Figs 17 and 18, respectively. Similarities 
in the two spectra are evident due to the presence of the $-\mathrm{SO}_{2}-$ units in the polymer chain, and are also similar to the spectrum for ethylene- $\mathrm{SO}_{2}$ determined previously. 3

\section{F. Conclusions}

(1) Overall polymerization rates and G-values were determined for Gas-phase Co-60 gamma copolymerication of Et-SO ${ }_{2}$ mixtures containing 19.2 mole\% $\mathrm{SO}_{2}$ initially at low pressure $(<5 \mathrm{~atm})$ in a system that was recharged repeatedly. For a dose rate of $0.54 \mathrm{Mrad} / \mathrm{hr}$ at $10-13^{\circ} \mathrm{C}$, peak G-values showed a general increase from $4.60 \times 10^{4}$ to $7.10 \times 10^{4}$ molecules/100 eV after six runs. The reaction time for attainment of peak rate decreased by a factor of 4.6 from 236 to $51 \mathrm{~min}$. The increased reactivity is attributed to the decreased vessel wall inhibition effect.

(2) The effect of hydrogen on the overall polymerization rate and G-value for gas-phase Co-60 gamma copolymerization of Et-SO 2 mixtures containing $19.2 \mathrm{~mole}_{2} \mathrm{SO}_{2}$ and 0,5 , and $10 \mathrm{mole \%} \mathrm{H}_{2}$ initially at $10 \mathrm{w}$ pressure ( $<5 \mathrm{~atm})$ were determined for a dose rate of $0.54 \mathrm{Mrad} / \mathrm{hr}$ at $10-13^{\circ} \mathrm{C}$. The 5 mole\% $\mathrm{H}_{2}$ mixture showed a slight decrease in reactivity, whereas the 10 mole\% $\mathrm{H}_{2}$ mixture showed a slight increase in reactivity when compared with previously obtained data for mixtures containing helium or nitrogen of the same concentration.

(3) The effect of oxygen on the overall polymerization rate and G-value for gas-phase Co-60 gamma copolymerization of a $\mathrm{Et}-\mathrm{SO}_{2}$ mixture containing 19.2 mole\% $\mathrm{SO}_{2}$ and $1.0 . \mathrm{mole} \% \mathrm{o}_{2}$ initially at low pressure (< $5 \mathrm{~atm}$ ) was determined for a dose rate of $0.54 \mathrm{Mrad} / \mathrm{hr}$ at $10-13^{\circ} \mathrm{C}$. The rate remained very low and constant for $900 \mathrm{~min}$ and then reached a peak after $1345 \mathrm{~min}$ total time for a G-value of $2.87 \times 10^{4}$ molecules/100eV. This factor of 6.7 
increase in reaction time for attainment of peak rate compared with a mixture containing no added oxygen is attributed to the inhibiting effect of oxygen on free-radical reactions.

(4) The overall polymerization rate and G-value were determined for gas-phase Co-60 gamma copolymerization of a 1-butene-SO $\mathrm{S}_{2}$ mixture containing approximately equimolar quantities initially at low pressure (< $5 \mathrm{~atm}$ ) for a dose rate of $0.56 \mathrm{Mrad} / \mathrm{hr}$ at $10-13^{\circ} \mathrm{C}$. The peak and overa11 G-values were 340 and 156 molecules/100eV, respectively. Analysis of the product indicated equimolar composition.

(5) Propylene- $\mathrm{SO}_{2}$ and 1-butene- $\mathrm{SO}_{2}$ copolymers were examined by DSC, TGA, and DTGA as well as infrared spectroscopy. TGA indicated stability

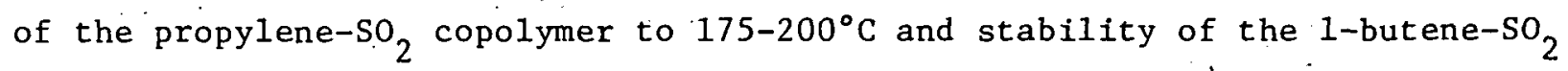
copolymer to $150^{\circ} \mathrm{C}$ compared with $300^{\circ} \mathrm{C}$ for $\mathrm{Et}-\mathrm{SO}_{2}$.

\section{Relocation of the Copolymer Studies Experimental Facility}

During this period, the copolymer studies facility was relocated from Bldg. 830 to Bldg. 528. A cobalt-60 source array (tube No. 8) containing nine source elements with a total activity of $5300 \mathrm{Ci}$ as of July 1979 was transferred to an existing stainless steel tank 6.4 feet in diameter by 11.7 feet deep containing approximately 2800 gal of water for shielding. This facility had been used previously for similar studies and required only a minimum amount of modification for the present program. For reason of safety, an outside radiation alarm system and a three-inch emergency water fill pipe were installed. The facility is shown in Fig. 19. 


\section{$\underline{\text { References }}$}

1. M. Steinberg, Polyketones and Polysulfones for Conservation of Ethylene Polymers, Chem. Engr. Prog. 72 (9), 75-79 (1976).

2. M. Steinberg, R. Johnson, W. Cordes, and D. Goodman, Polyketones and Polysulfones for Conservation in the Ethylene Polymer Industry, Progress Report No. 1, October-December 1977, BNL 50884.

3. M. Steinberg, R. Johnson, W. Cordes, and D. Goodman, Polyketones and Polysulfones for Conservation in the Ethylene Polymer Industry, Progress Report No. 2, April-September 1978, BNL 50955.

4. M. Steinberg, R. Johnson, W. Cordes, and D. Goodman, Polyketones and Polysulfones for Conservation in the Ethylene Polymer Industry, Progress Report No. 3; October-Deceraber 1978; BAL_50984.

5. M. Steinberg, R. Johnson, W. Cordes, and D. Goodman, Polyketones and Polysulfones for Conservation in the Ethylene Polymer Industry, Progress Report No. 4, January-March 1979, BNL 51034.

6. M. Steinberg, R. Johnson, W. Cordes, and D. Goodman, Polyketones and Polysulfones for Conservation in the Ethylene Polymer Industry, Progress Report No. 5, April-June 1979, BNL 51080.

7. Bravo et a1., Petroleum Chemistry 4 , 141-2 (1964). 
Table 1

Et-CO COPOLYMERS - CHARACTERIZATION

IR Absorbance

\begin{tabular}{|c|c|c|c|c|c|c|c|c|c|c|}
\hline Sample No. & Catalyst & $\%$ CO & $\begin{array}{l}\text { Melting } \\
\text { Point, }{ }^{\circ} \mathrm{C} \\
\end{array}$ & $\underline{1400}$ & $\underline{1450}$ & 1325 & $\underline{800}$ & $\begin{array}{l}1450 / \\
1400 \\
\end{array}$ & $\begin{array}{l}1325 / \\
1400 \\
\end{array}$ & $\begin{array}{l}800 / \\
1400 \\
\end{array}$ \\
\hline E099-29 & Free Rad. & 28.7 & 90 & 0.449 & 0.219 & 0.007 & 0.005 & 0.488 & 0.016 & 0.011 \\
\hline E099-13 & Free Rad. & 36.8 & 98.5 & 1.241 & 0.408 & 0.052 & 0.021 & 0.329 & 0.042 & 0.017 \\
\hline E099-28 & Free Rad. & 37.8 & 102.5 & 1.010 & 0.328 & 0.040 & 0.027 & 0.325 & 0.040 & 0.027 \\
\hline E099-30 & Free Rad. & 38.3 & 102.5 & 0.532 & 0.146 & 0.026 & 0.022 & 0.274 & 0.049 & 0.041 \\
\hline E099-31 & Free Rad. & 41.8 & 141 & 0.741 & 0.129 & 0.108 & 0.056 & 0.174 & 0.146 & 0.076 \\
\hline EO9.9-54BR & $\mathrm{Co}^{60}$ & 42.1 & 129 & 0.549 & 0.134 & 0.078 & 0.034 & 0.244 & 0.142 & 0.062 \\
\hline E099. & Metal & 48.9 & & 0.966 & - & 0.547 & 0.131 & - & 0.566 & 0.136 \\
\hline EO99-70BR & $\mathrm{Co}^{60}$ & 49.1 & 215 & 0.861 & 0.018 & 0.440 & 0.090 & 0.021 & 0.511 & 0.104 \\
\hline E156-148-1 & $\mathrm{Co}^{60}$ & 46.4 & 198 & 0.643 & 0.043 & 0.250 & 0.074 & 0.067 & 0.389 & 0.115 \\
\hline E156-148-2 & $\mathrm{Co}^{60}$ & 47.2 & 206 & 0.550 & 0.015 & 0.221 & 0.052 & 0.027 & 0.402 & 0.095 \\
\hline E156-148-3 & $\mathrm{Co}^{60}$ & 47.4 & 210.5 & 0.993 & 0.038 & 0.417 & 0.199 & 0.038 & 0.420 & 0.200 \\
\hline E156-148-4 & $\mathrm{Co}^{60}$ & 47.4 & 210.5 & 0.662 & 0.019 & 0.307 & 0.054 & 0.029 & 0.464 & 0.082 \\
\hline E156-148-5 & $\mathrm{Co}^{60}$ & 47.1 & 213 & 0.622 & 0.013 & 0.292 & 0.056 & 0.021 & 0.469 & 0.090 \\
\hline E156-148-6 & $\mathrm{Co}^{60}$ & 47.8 & 219 & 0.815 & 0.021 & 0.365 & 0.116 & 0.026 & 0.448 & 0.142 \\
\hline E156-148-7 & $\mathrm{Co}^{60}$ & 47.3 & 207 & 1.013 & 0.035 & 0.440 & 0.119 & 0.035 & 0.434 & 0.117 \\
\hline E156-150-1 & $\mathrm{Co}^{60}$ & 48.1 & 218 & 0.825 & 0.019 & 0.406 & 0.086 & 0.023 & 0.492 & 0.104 \\
\hline E156-150-2 & $\mathrm{Co}^{60}$ & 48.1 & 224 & 0.493 & 0.008 & 0.223 & 0.056 & 0.016 & 0.452 & 0.114 \\
\hline E156-150-3 & $\mathrm{Co}^{60}$ & 48.7 & 219 & 0.690 & 0.013 & 0.298 & 0.086 & .019 & 0.432 & .125 \\
\hline E156-150-4 & $\mathrm{Co}^{60}$ & 47.2 & 209 & $0.932^{\circ}$ & 0.033 & 0.420 & 0.093 & 0.035 & 0.451 & 0.100 \\
\hline E156-150-5 & $\mathrm{Co}^{60}$ & 47.5 & 219 & 0.970 & 0.016 & 0.463 & 0.108 & 0.016 & 0.477 & 0.111 \\
\hline E156-150-6 & $\mathrm{Co}^{60}$ & 47.3 & 209 & 0.728 & 0.016 & 0.362 & 0.064 & 0.022 & 0.497 & 0.088 \\
\hline E156-150-7 & $\mathrm{Co}^{60}$ & 48.0 & 206 & 0.910 & 0.021 & 0.424 & 0.091 & 0.023 & 0.456 & 0.100 \\
\hline E156-150-8 & $\mathrm{Co}^{60}$ & 47.1 & 217 & 0.907 & 0.018 & 0.459 & 0.084 & 0.020 & 0.506 & 0.093 \\
\hline E156-150-9 & $\mathrm{Co}^{60}$ & 47.3 & 214.5 & 1.228 & 0.020 & 0.590 & 0.146 & 0.016 & 0.480 & 0.119 \\
\hline $151-1$ & $\mathrm{Co}^{60}$ & 47.1 & 217 & $0.803^{\circ}$ & 0.014 & 0.395 & 0.083 & 0.017 & 0.491 & 0.103 \\
\hline $51-2$ & $\mathrm{Co}^{60}$ & 47.2 & 05 & 0.720 & 0.017 & 0.325 & 0.060 & 0.024 & 0.451 & 0.083 \\
\hline E156-151-3 & $\mathrm{Co}^{60}$ & 47.0 & 205.5 & 1.018 & 0.021 & 0.519 & 0.100 & 0.021 & 0.510 & 0.098 \\
\hline E156-151-4 & $\mathrm{Co}^{60}$ & 46.9 & 201 & 0.752 & 0.028 & 0.341 & 0.079 & 0.037 & 0.453 & 0.105 \\
\hline E156-151-5 & $\mathrm{Co}^{60}$ & 47.0 & 204 & 0.876 & 0.025 & 0.413 & 0.093 & 0.029 & 0.471 & 0.106 \\
\hline E156-151-6 & $\mathrm{Co}^{60}$ & 48.2 & 216 & 0.672 & 0.014 & 0.326 & 0.078 & 0.021 & 0.485 & 0.116 \\
\hline $56-151-7$ & $\mathrm{Co}^{60}$ & 47.5 & 215 & 0.546 & 0.012 & 0.271 & 0.070 & 0.022 & 0.496 & 0.128 \\
\hline $.51-8$ & $\mathrm{Co}^{60}$ & .8 & 2.5 & 0.914 & 0.020 & 0.458 & 0.105 & 022 & 0.501 & 115 \\
\hline $156-151-9$ & $\mathrm{Co}^{60}$ & 46.6 & 213 & 0.617 & 0.014 & 0.259 & 0.056 & 0.023 & 0.420 & 091 \\
\hline
\end{tabular}




\section{Et-CO COPOLYMERS - THERMAL DEGRADATION}

Samples heated for $1 \mathrm{hr}$

\begin{tabular}{|c|c|c|c|c|c|c|c|}
\hline \multirow[b]{2}{*}{ Sample No. } & \multirow[b]{2}{*}{$\% \mathrm{CO}$} & \multirow[b]{2}{*}{ Temp.,${ }^{\circ} \mathrm{C}$} & \multirow[b]{2}{*}{$\underline{a t m}$} & \multirow[b]{2}{*}{ Color } & \multicolumn{3}{|c|}{ IR Absorbance } \\
\hline & & & & & 1400 & 1325 & $1325 / 1400$ \\
\hline E099-143 & 48.9 & 25 & Air & & 0.966 & 0.547 & 0.566 \\
\hline E099-143 & 48.9 & 70 & Air & & 0.940 & 0.547 & 0.582 \\
\hline E099-143 & 48.9 & $\cdot 70$ & $\mathrm{~N}_{2}$ & & 0.723 & 0.412 & 0.570 \\
\hline E099-143 & 48.9 & 140 & Alr & & 1.024 & 0.567 & 0.553 \\
\hline E099-143 & 48.9 & 140 & $\mathrm{~N}_{2}$ & & 0.953 & 0.537 & 0.563 \\
\hline E099-143 & 48.9 & 210 & Air & & 0.723 & 0.297 & 0.411 \\
\hline E099-143 & 48.9 & 210 & $\mathrm{~N}_{2}$ & & 0.338 & 0.168 & 0.497 \\
\hline E099-143 & 48.9 & 280 & Air & & 0.360 & 0.006 & 0.017 \\
\hline E099-143 & 48.9 & 280 & $\mathrm{~N}_{2}$ & & 0.510 & 0.025 & 0.049 \\
\hline E099-70BR & 49.1 & 25 & Air & White & 0.861 & 0.440 & 0.511 \\
\hline E099-70BR & 49.1 & 70 & Air & White & 0.882 & 0.429 & $0.486^{\prime}$ \\
\hline E099-70BR & 49.1 & 70 & $\mathrm{~N}_{2}$ & White & 0.641 & 0.286 & 0.446 \\
\hline E099-70BR & 49.1 & 140 & Airr & White/Yellow & 0.643 & 0.307 & 0.477 \\
\hline EO99-70BR & 49.1 & 140 & $\mathrm{~N}_{2}$ & White/Yellow & 0.571. & 0.279 & 0.489 \\
\hline E099-70BR & 49.1 & 210 & Air & Black & 0.390 & 0.072 & 0.185 \\
\hline E099-70BR & 49.1 & 210 & $\mathrm{~N}_{2}$ & Brown & 0.452 & 0.169 & 0.374 \\
\hline E131-32 & 45.4 & - & - & & 1.293 & 0.756 & 0.585 \\
\hline E131-32 & 45.4 & (a) & - & & 0.760 & 0.272 & 0.358 \\
\hline
\end{tabular}

$\overline{(a)}$ Press molded at $260^{\circ} \mathrm{C}$ for $5 \mathrm{~min}$. 
Table 3

LOW-PRESSURE GAS-PHASE Co-60 GAMMA COPOLYMERIZATION

OF Et-SO 2 IN RECHARGED SYSTEM

Irradiation Temp.: $10-13^{\circ} \mathrm{C}$

Radiation Intensity: $0.54 \mathrm{Mrad} / \mathrm{hr}$

Initial Mole \% SO : 19.2

Initial Press: $65.2-69.4$ psia

Final Press: $41.3-44.0$ psia

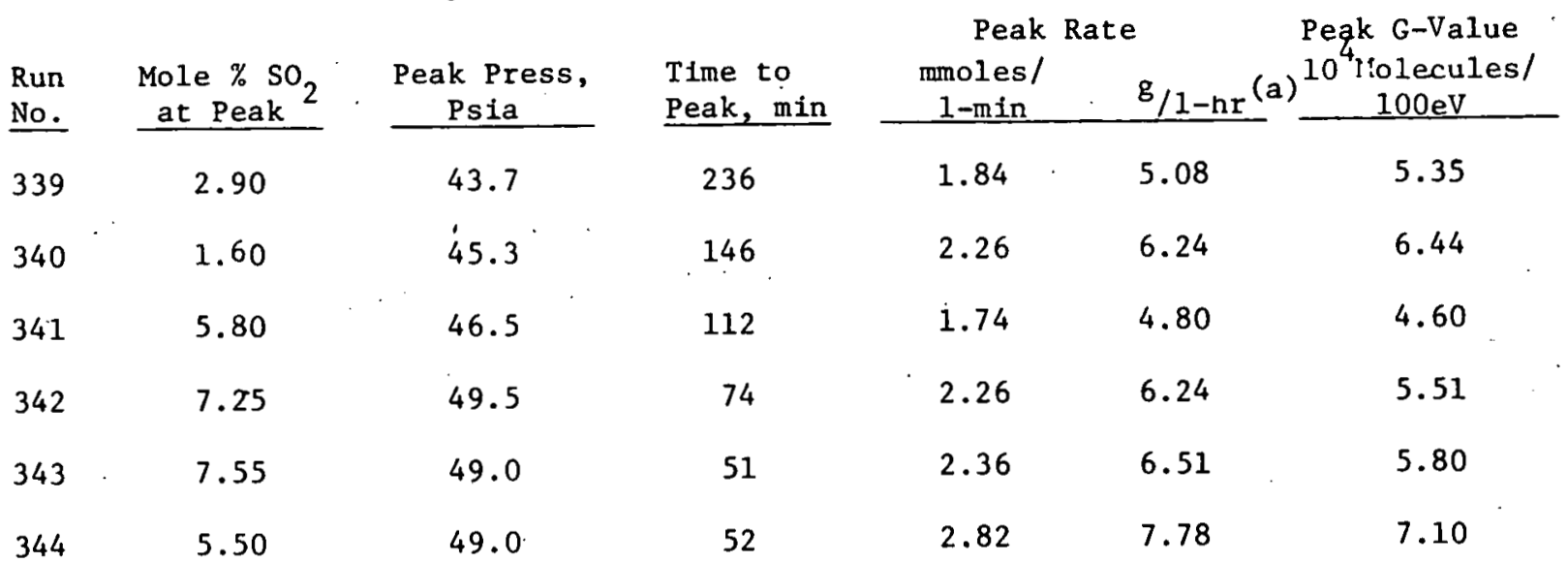

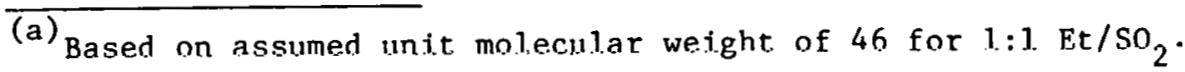


LOW-PRESSURE GAS-PHASE CO-60 GAMMA COPOLYMERIZATION OF Et-SO 2

\section{MIXTURES CONTAINING HYDROGEN}

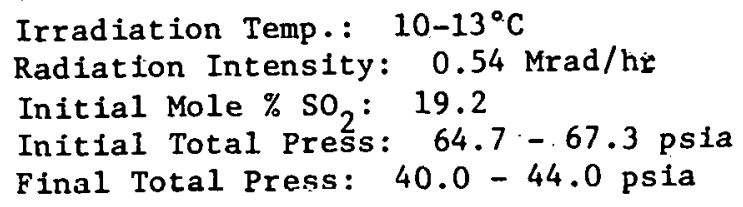

\begin{tabular}{|c|c|c|c|c|c|c|c|c|}
\hline $\begin{array}{l}\text { Run } \\
\text { No. }\end{array}$ & $\begin{array}{r}\text { Mole } \\
\text { Initial }\end{array}$ & $\begin{array}{l}\% \mathrm{H}_{2} \\
\text { At Peak }\end{array}$ & $\begin{array}{c}\text { Mole } \% \mathrm{SO}_{2} \\
\text { At Peak }\end{array}$ & $\begin{array}{l}\text { Peak } \\
\text { press, } \\
\text { psia }\end{array}$ & $\begin{array}{r}\text { Time To } \\
\text { Peak, min }\end{array}$ & $\begin{array}{r}\text { Peak } \\
\text { mmoles/ } \\
1 \text {-min } \\
\end{array}$ & $\begin{array}{l}\text { Rate } \\
\qquad g / 1-h(a)\end{array}$ & $\begin{array}{c}\text { Peak G-Value } \\
10^{4} \text { Molecules } / \\
100 / \text { ev }\end{array}$ \\
\hline 339 & 0 & 0.0 & 2.90 & 43.7 & 236 & 1.81 & 5.08 & 5.35 \\
\hline 346 & 5 & 7.8 & 0.85 & 42.7 & 302 & 1.43 & 3.95 & 4.79 \\
\hline 347 & 5 & 7.5 & 3.36 & 44.3 & 288 & 1.49 & 4.11 & 4.79 \\
\hline 345 & 10 & 14.9 & 1.47 & 45.2 & 308 & 1.38 & 3.81 & 4.71 \\
\hline 350 & 15 & 23.7 & 1.23 & 41.0 & 580 & 0.84 & 2.32 & 3.54 \\
\hline
\end{tabular}

(a) Based on assumed un1t molecular weight of 46 for $1: 1 \mathrm{Et} / \mathrm{SO}_{2}$.

Table 5

$\frac{\text { THERMAL PROPERTIES OF PROPYLENE-SO }}{\text { Copolymers }} 2 \frac{\text { AND 1-Butene-SO }}{2}$

\begin{tabular}{|c|c|c|c|c|c|}
\hline $\begin{array}{l}\text { Run } \\
\text { No } \\
\end{array}$ & Copolymer & Mole $\% \mathrm{SO}_{2}$ & $\begin{array}{c}\text { DSC } \\
\text { Peak Melting or } \\
\text { Transition, }{ }^{\circ} \mathrm{C}\end{array}$ & $\begin{array}{c}\text { TGA } \\
\text { Onset of } \\
\text { decomposition, }{ }^{\circ} \mathrm{C} \\
\end{array}$ & $\begin{array}{c}\text { DTGA (a) } \\
\text { Peak } \\
\text { decomposition, }{ }^{\circ} \mathrm{C} \\
\end{array}$ \\
\hline 316 & Propylene- $\mathrm{SO}_{2}$ & 49.0 & 215 & 175 & $325(305)$ \\
\hline 322 & Propylene-SO $\mathrm{S}_{2}$ & 49.8 & 155 & 200 & $325(305)$ \\
\hline 319 & 1 -Butene- $\mathrm{SO}_{2}$ & 48.2 & 75,180 & 150 & $325(220)$ \\
\hline
\end{tabular}

(a) Secondary peak shown in parenthesis. 


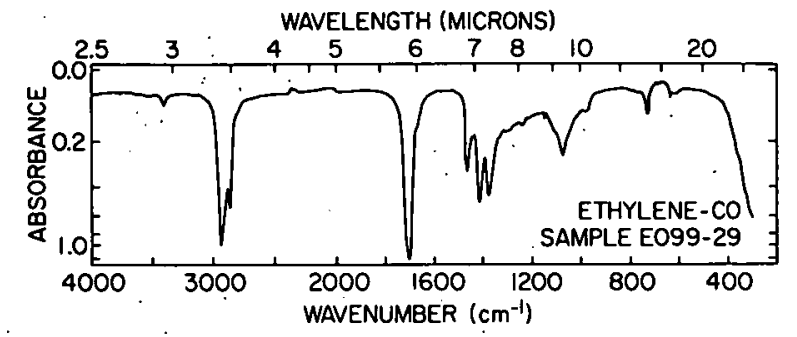

Figure 1. Infrared spectrum of Et-CO copolymer sample E099-29

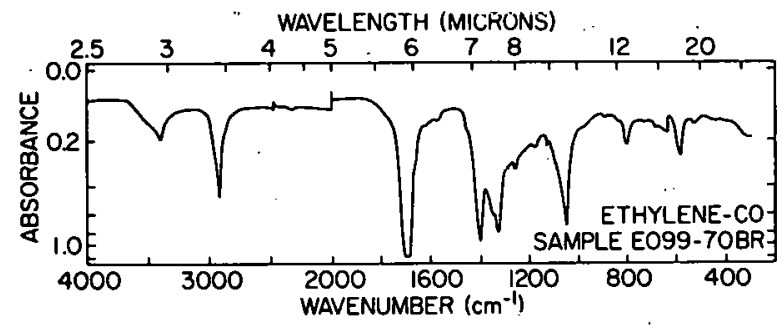

Figure 2. Infrared spectrum of Et-CO copolymer sample E099-70BR

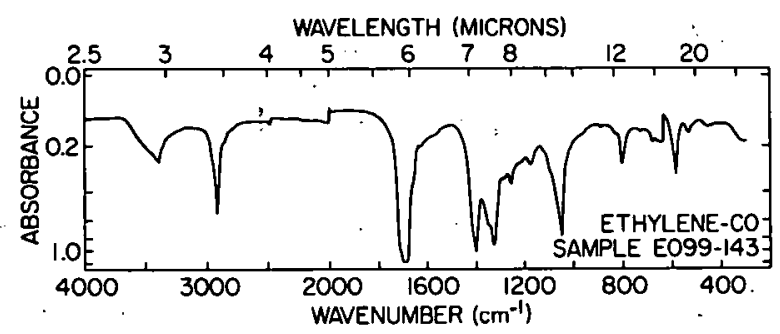

Figure 3. Infrared spectrum of Et-CO copolymer sample E099-143 .. 


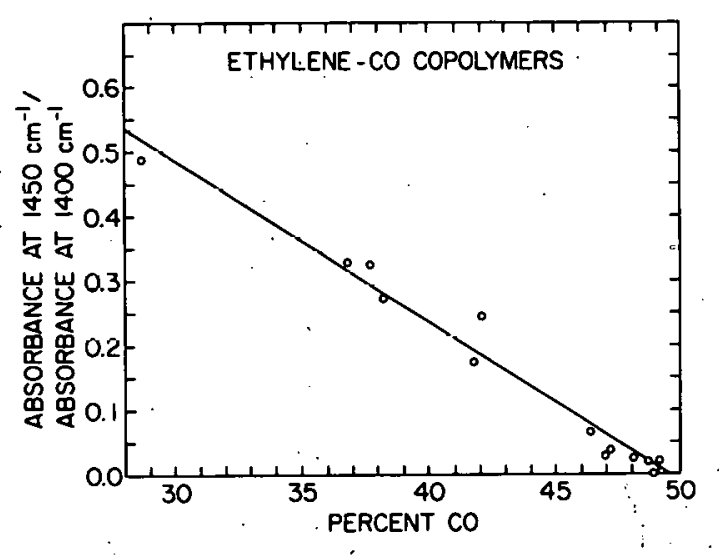

Figure 4. Normalized infrared absorbance of Et-CO copolymers at $1450 \mathrm{~cm}^{-1}$

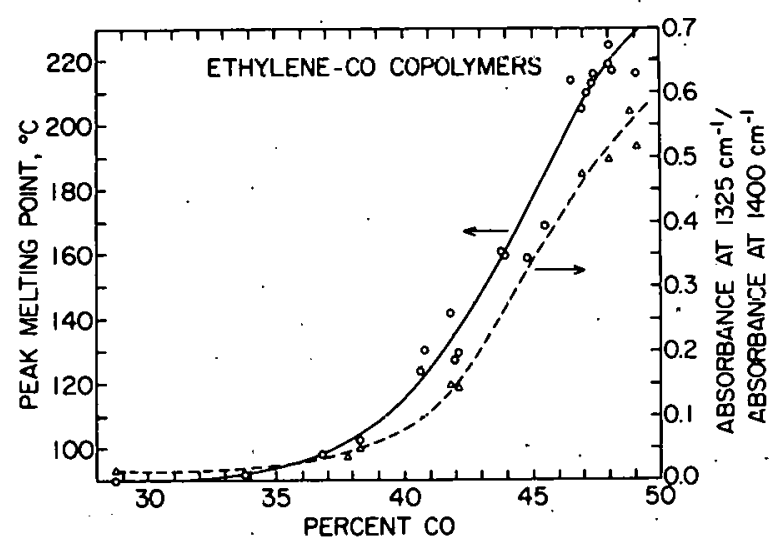

Figure 6. Peak melting point and normalized infrared absorbance of Et-CO copolymers at $1325 \mathrm{~cm}^{-1}$

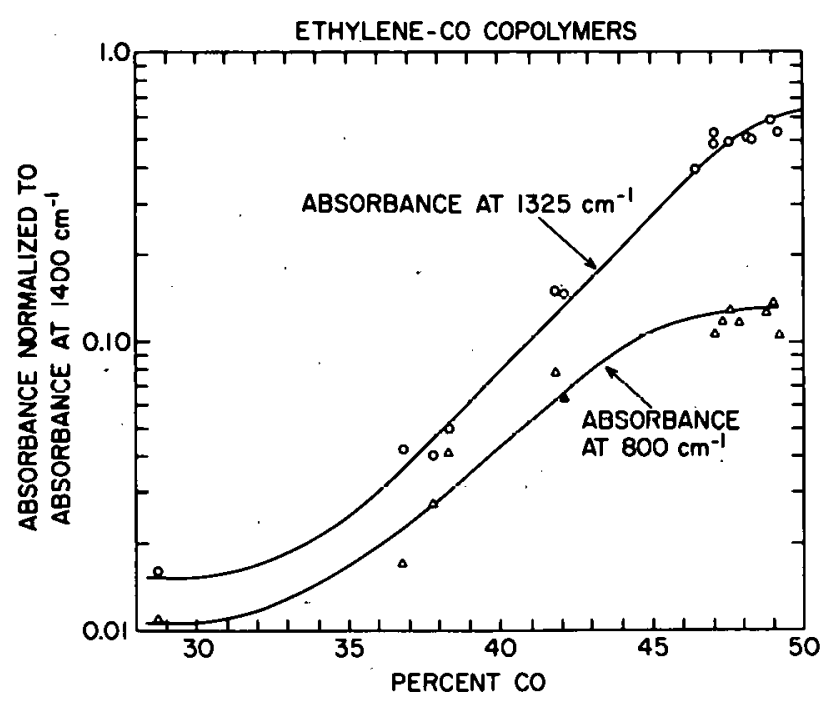

Figure 5. Normalized infrared absorbance of Et-CO copolymers at 1325 and $800 \mathrm{~cm}^{-1}$

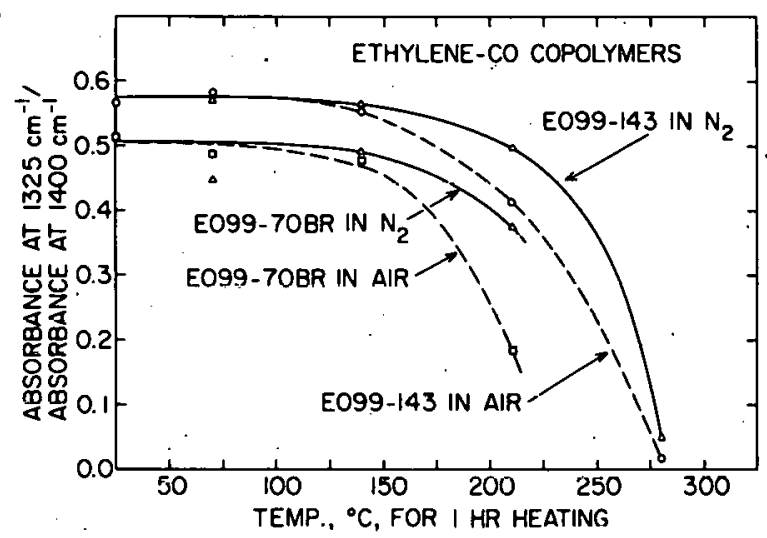

Figure 7. Normalized infrared absorbance of heated Et-CO copolymers at $1325 \mathrm{~cm}^{-1}$. 


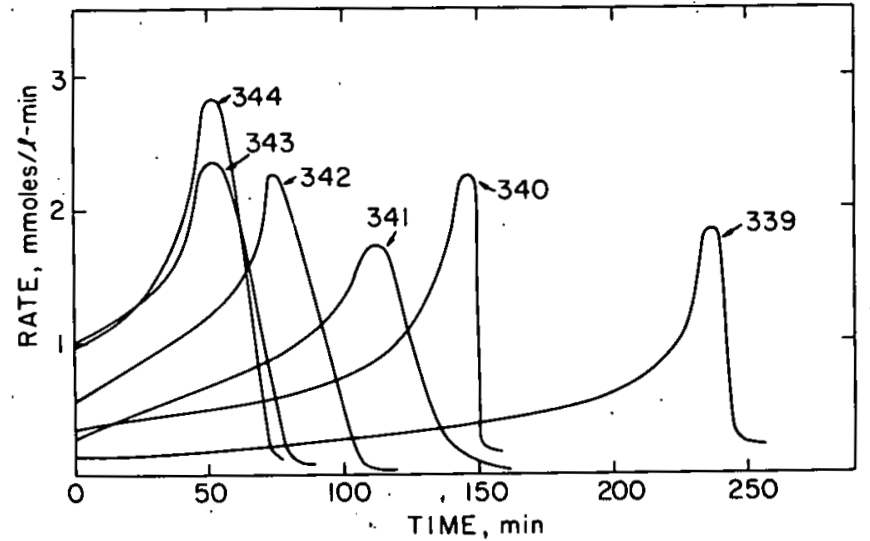

Figure 8. Gas-phase Co-60 gamma copolymerization of $\mathrm{Et}-\mathrm{SO}_{2}$ in recharged systems (Runs 339-344). Rate vs. time

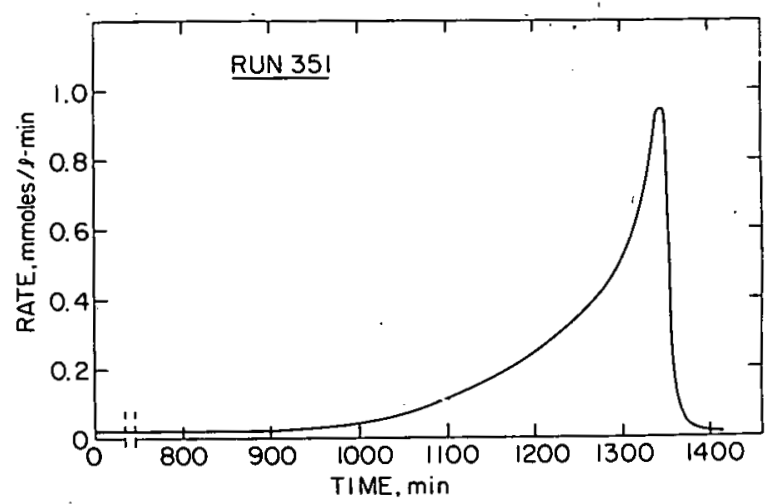

Figure 10. Gas-phase Co-60 Gamma copolymerization of $\mathrm{Et}-\mathrm{SO}_{2}$ containing $1 \%$ oxygen. Rate vs. time

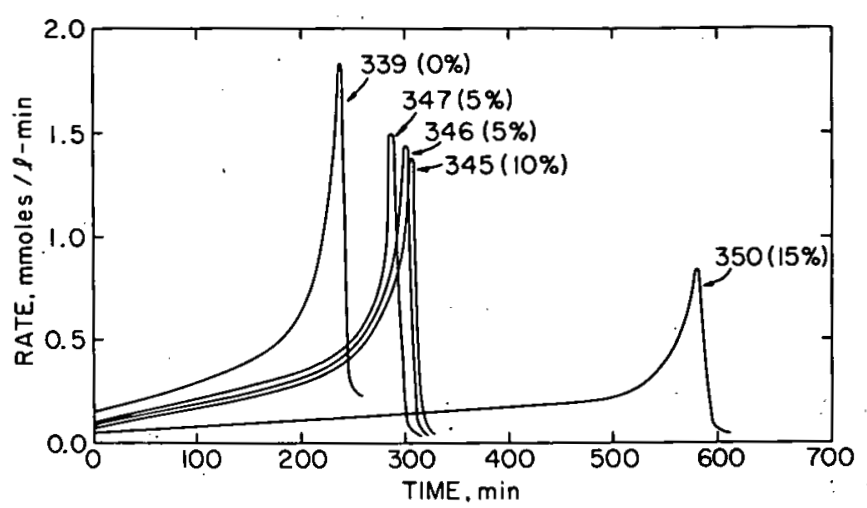

Figure 9. Gas-phase Co-60 gamma copolymerization of Et-SO $\mathrm{S}_{2}$ containing 0,5 , and $10 \%$ hydrogen. Rate vs. time

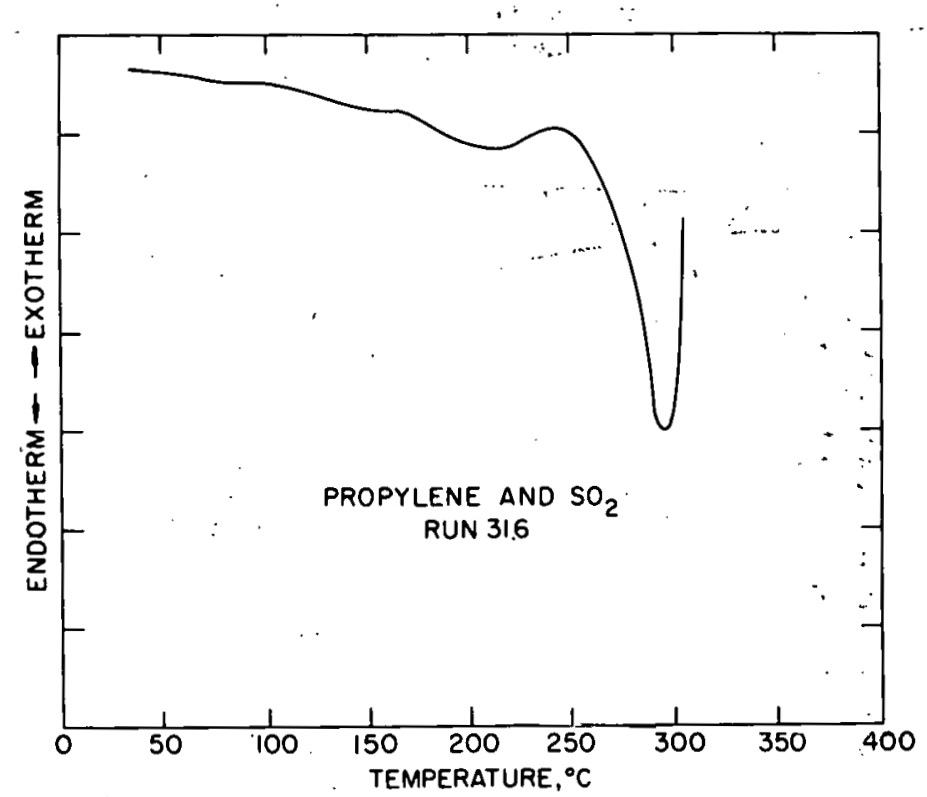

Figure 11. Differential scanning calorimetry for propylene- $\mathrm{SO}_{2}$ copolymer from run 316 


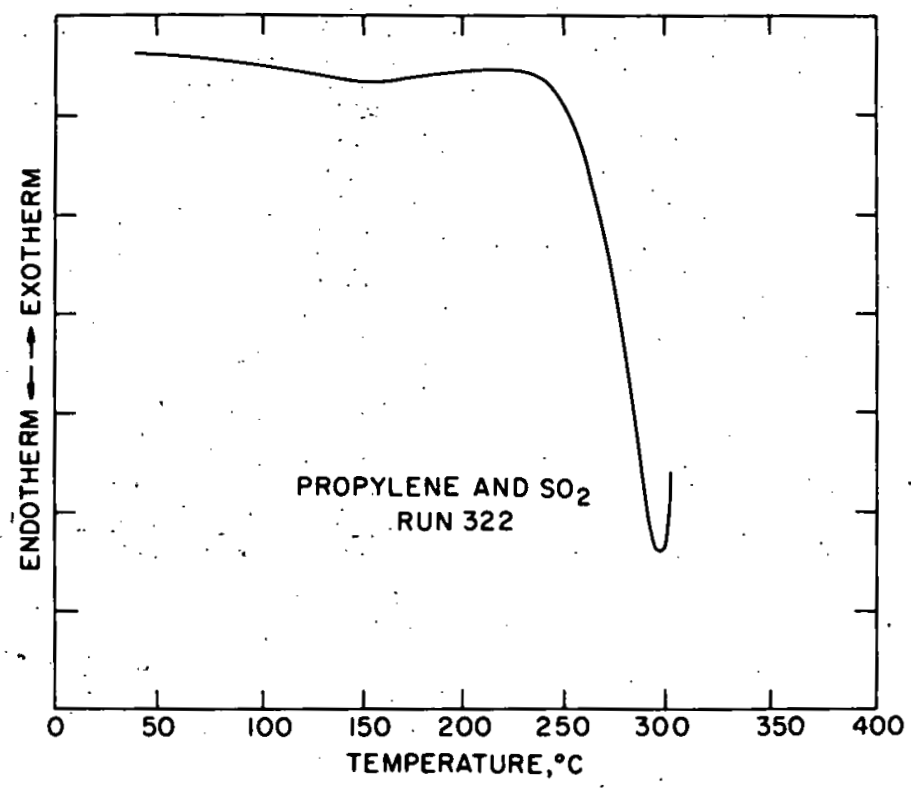

Figure 12. Differential scanning calorimetry for propylene- $\mathrm{SO}_{2}$ from run 322

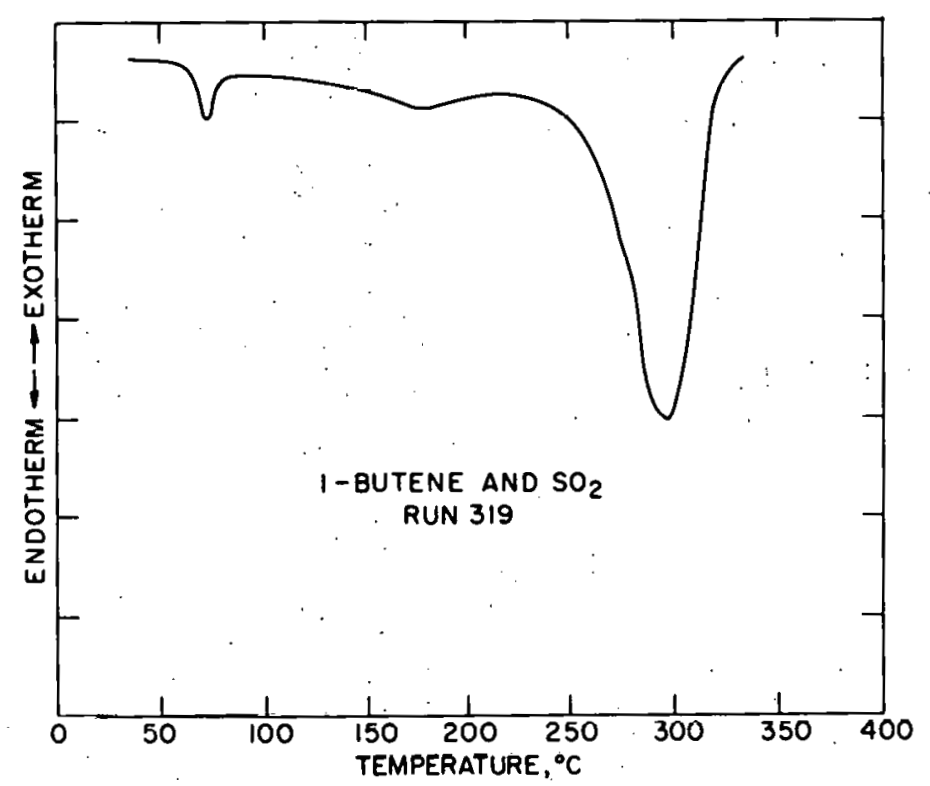

Figure 13. Differential scanning calorimetry for 1-butene- $\mathrm{SO}_{2}$ copolymer from run 319

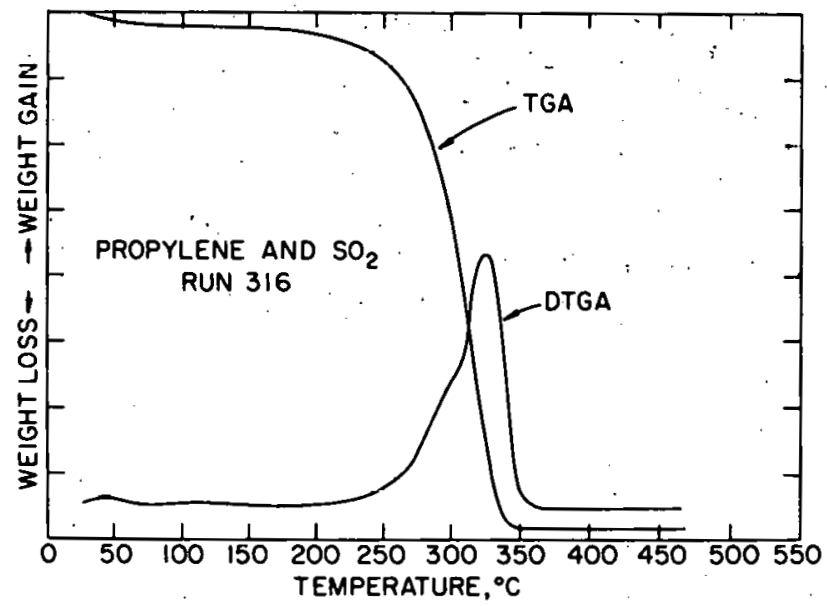

Figure 14. Thermogravimetric analysis of propylene- $\mathrm{SO}_{2}$ copolymer from run 316 


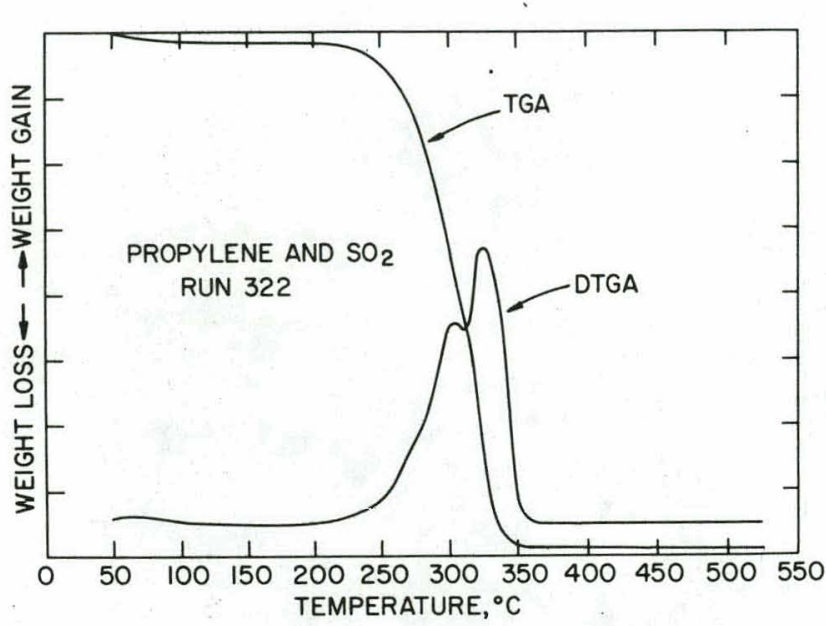

Figure 15. Thermogravimetric analysis of propylene- $\mathrm{SO}_{2}$ copolymer from run 322

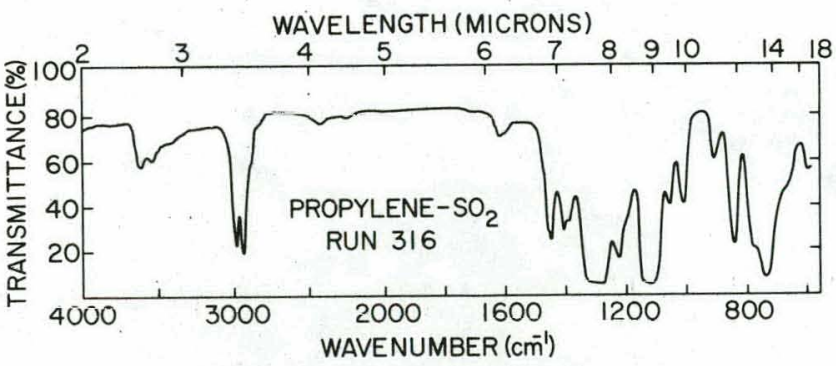

Figure 17. Infrared spectrum of propylene- $\mathrm{SO}_{2}$ copolymer from run 316

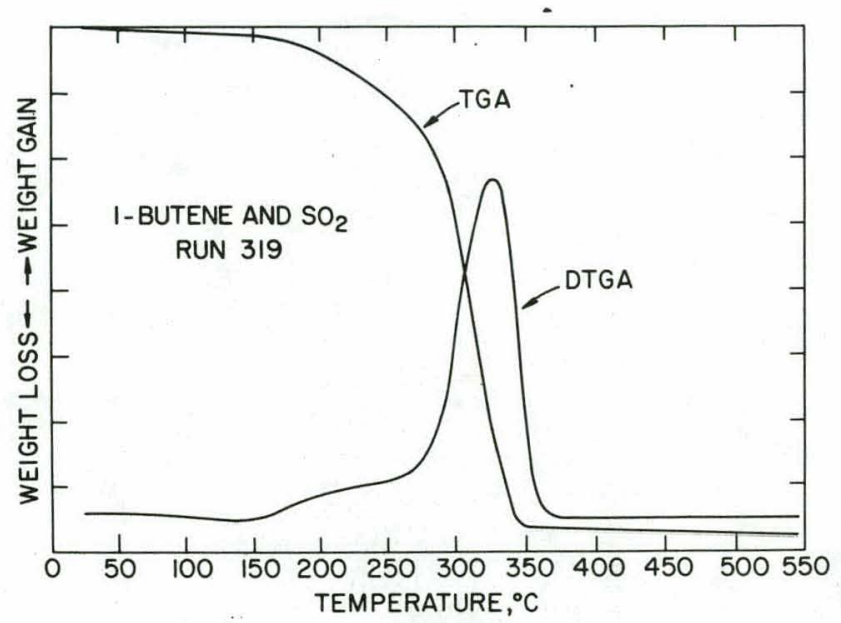

Figure 16. Thermogravimetric analysis of 1-butene- $\mathrm{SO}_{2}$ copolymer from run 319

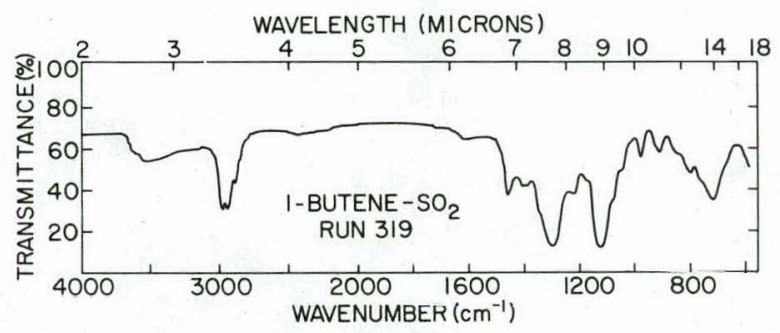

Figure 18. Infrared spectrum of 1-butene- $\mathrm{SO}_{2}$ copolymer from run 319 


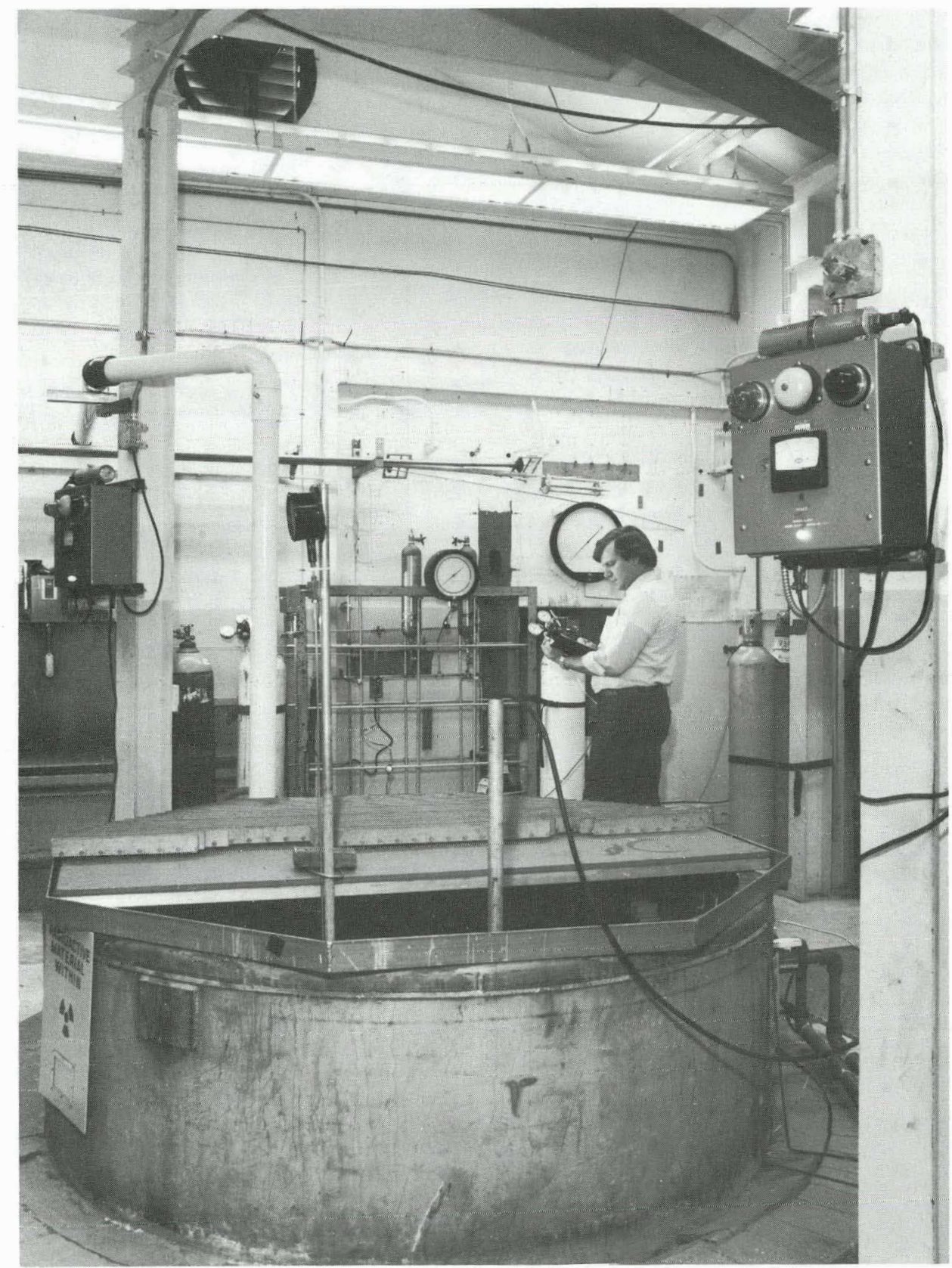

Figure 19. Co-60 gamma facility in copolymer studies laboratory - B1dg. 528 